\title{
Analysis of Socio-Ecological Impacts of Built Environment at Dar es Salaam Metropolitan Coastline, Tanzania
}

\author{
Mkama Thomas Manyama ${ }^{1 *}$, Aloyce Shaban Hepelwa ${ }^{2}$, Cuthbert Leonard Nahonyo ${ }^{1}$ \\ ${ }^{1}$ Department of Zoology and Wildlife Conservation, University of Dar es Salaam, Dar es Salaam, Tanzania \\ ${ }^{2}$ Department of Agricultural Economics and Business, University of Dar es Salaam, Dar es Salaam, Tanzania \\ Email: *mkama.ma@gmail.com
}

How to cite this paper: Manyama, M.T., Hepelwa, A.S. and Nahonyo, C.L. (2019) Analysis of Socio-Ecological Impacts of Built Environment at Dar es Salaam Metropolitan Coastline, Tanzania. Open Journal of Social Sciences, 7, 161-182. https://doi.org/10.4236/jss.2019.710014

Received: August 27, 2019

Accepted: October 18, 2019

Published: October 21, 2019

Copyright $\odot 2019$ by author(s) and Scientific Research Publishing Inc. This work is licensed under the Creative Commons Attribution International License (CC BY 4.0).

http://creativecommons.org/licenses/by/4.0/

\begin{abstract}
This paper analyzed and mapped the impact of built environment (BE) on socio-ecological services along Dar es Salaam metropolitan coastline. In the period of 1995-2016, burgeoning population exacerbated high rate of construction processes and activities. Such anthropic initiatives affect the benefits and values delivered by landscape wetlands, estuaries, beach areas, open space and greenery patches in Dar es Salaam coastline. Motivated to understanding socio-ecological impacts (SEIs) of BE along the coastline; the study applied focus group discussions (FGDs) method to identify SEIs, and their category as either positive or negative. Using analytical hierarchy process (AHP) generated weight to each SEIs; thereafter combined that weight with landuse landcover (LULC) change statistics of each of the 67 wards involved in the study. Mapping results of geographically weighted regression and inverse distance weighting (IDW) interpolation (ArcMap v10.3) displayed the variables relationship magnitudes and distribution in positive and negative SEIs for year 1995, 2005 and 2016.
\end{abstract}

\section{Keywords}

Socio-Ecological Impacts, Built Environment, Panel Regression Analysis, GWR, AHP, Geospatial Interpolation

\section{Introduction}

The wholeness understanding of coupled human-environment interactions [1] [2] involves seamless biophysical, social and economic factors [3]. The flow and use of these factors at spatial, temporal and organizational scale are under control of complex combination of feedback mechanisms from environmental, eco- 
logical and social systems [4]. Such intertwining feedbacks results in complex systemic relationship, termed as socio-ecological system (SES) [5] [6] [7].

Existence of human desire for improved economic and social services in SES are external stimuli to coastline resources utilization hence degradation of ecological system [5]. Studies [8] explain that coastline, also referred to as coastal zone, ranges from 60 to 200 kilometre inland and $50 \mathrm{~m}$ depth of ocean water system. In between exists highly fertile areas like continental shelf, estuaries and wetlands at both low and high tide periods [9]; these fertile characters are a reason for dominant human perturbation in such areas [10] [11]. While [12] justified the relationship of anthropogenic activities and coastal zone, little has done to disclose the existing link of BE and its impact on SES.

$\mathrm{BE}$ as a product of construction activities [13], in the search for suitable and comfortable places for recreation, residence and work; impacts the landscape by aggravating vegetation cover clearance, waste generation and permanent consumption of a piece of land [14] [15]. The habitat loss and fragmentation caused by such impacts account significantly for biodiversity loss. According to [16], the functioning of biodiversity species are greatly the determinant of the quality and quantity of services derived from SES. Thus, state of landscape loss or gain of such biological component is a socio-ecological impact (SEI) that alters SES functioning capacity [17]. Scholars such as [18] and [19] typify that some of the positive SEIs include cooling, shadow, air filtration, climate variability and flood prevention by trees; pollinations by avian and arthropods species as well as medicines and food from both fauna and flora.

However, irreversible anthropic construction activities provoke landscape environmental challenges as result of megacities development processes and activities [20] [21]. In the search for quality product of BE, demolition is part-and-parcel in construction sector, thus construction and demolition (C \& D) terminology [22]. From global-to-regional-to-local settings, C \& D depicts serious challenges affecting SES [23]. Global statistics show that C \& D activities worth one million US\$, generates 28 to 121 tons of wastes with variations observed among countries [24]. Waste generation stream in C \& D activities extends to involving excavation and extraction of resources such as rock and soil, waste asphalt, concrete, bricks, timber and vegetation, plasterboard, asbestos and contaminated soil. Studies [25] epitomize that in developing countries such wastes constitute between 25 to 55 percent of municipal waste reaching the landfill; consequently contributing hugely to environmental degradation. According to [26] C \& D wastes generation indicates the rate of urbanization, economic and social activities, which altogether exacerbate environmental degradation in the coastal zone cities such as Dar es Salaam. Indirect and direct downsizing of marshes, water, fen or peatland in a wetland by BE shapes the SEIs as well as SES capacity to deliver such impacts, thus negative SEIs [27] [28].

Further studies [29] [30] [31] exemplify that the ancillary impact of BE is on its ability to create novel habitats. These non-natural habitats like constructed wetland, home planted trees, pavements, and backyard and flower gardens are 
instrumental on SEIs to urbanites. [32] and [33] epitomize that some BE characteristics like household debris and roadside tree strips influence existence of urban species that can co-exist with human being, hence, increase biodiversity species in a human-dominated landscape. Furthermore, changes in biogeochemical cycles linked to urban BE emission, atmospheric flow and sea breezes interaction present more impact to SES [34]. The response of different biodiversity species, in particular, human being to changes happening in the SES differ significantly [35]; similarly the perceptions of negative and positive SEIs.

Nonetheless, practically, positive and negative impacts of $\mathrm{BE}$ do co-exist in the same SES, in a way that feedback of either side triggers differently the SES [36]. This being the case, the positive or negative perception of coastal urbanites on SEIs is likely not to be permanent [37]. Therefore, this paper driven by the objective to understanding the interactions between human being, construction activities, built environment and natural resources; analyzed the perceived SEIs of BE in the coastline of Dar es Salaam Metropolitan. Furthermore, the research sought the correlation between vegetation, $\mathrm{BE}$ and agricultural landscape in the study area for the past 21 years, from 2016.

\section{Literature Review}

Socio-ecological system (SES) as a scientific discipline emerged from social ecological theory, which is rooted in the general system theory (the interdisciplinary study of systems) [38]. Studies [39] [40] reveal the existing high demand of interdisciplinary and transdisciplinary approaches toward investigating the interplay and interrelationships of human and natural systems. Despite the fact that interdisciplinary approaches have used in research for decades [38], the past two decades has seen huge application of SES in explaining the interactions in and between factors in the field of environmental sciences, economics, social sciences as well as medicines and psychology [41] [42]. Scholars on interdisciplinary study of systems provide five levels of interactions that govern the SES [43], interaction levels such as intra-individual, interindividual, organization, community and macropolicy profoundly influence interdependent changes [41]. Changes inside an individual in one level influences changes to neighbouring individual and level, hence the mutual influence and effect at one level impacts diversely and variously at another level [44] [45]. According to [13] [46] environmental changes due BE while ensure places for work, residence and recreation, its influences largely result into loss of natural biome habitats. The pace of population growth has promoted urbanization, which in turn disrupts and degrades nature and environmental resources, in particular, ecological system [13] [47].

Scholars depict that the impacts of construction activities as irreversible [15]. The socio-economic impacts of $\mathrm{BE}$ is associated with its characteristics of taking and seating permanently on a piece of land [5] [48] [49], thus restricting the biomes connectedness [11] [18] [44] [50] [51]. According to [10] [11] BE notably 
human settlements account for significant changes of global landscapes, hence pose serious challenges socially, economically and environmentally. While construction and demolition industry that result into BE account for huge employment and income generation [22] [25] [26], nevertheless its impacts to ecological systems threatens the global community [22] [25] [26] [47] [52] [53]. Public health research [1] [41] [46] reveal the association of physical exercise and urban planning, the absence of space and green infrastructure is reported to influencing public health problems [54].

Despite varying challenges associated with $\mathrm{BE}$; on the other hand studies [8] [29] [30] epitomize the significant roles of BE on creating novel habits for urban biodiversity. Furthermore, presence of debris, home and roadside trees as novel habitats in urban settings influence presence of biodiversity at varying degrees [30]. All biodiversity species that can co-exist in human dominated environment are likely to flourish [29], while weak species in human dominated landscape are likely to escape into different habitats. In either case the degree of biodiversity heterogeneity in a particular landscape is pivotal to an efficient and effective functioning of SES [6] [16] [43] [55] [56], in the context of assuring supply and access to ecosystem services.

\section{Material and Methods}

\subsection{Study Area}

Dar es Salaam metropolitan is located between Latitude $6^{\circ} 3^{\prime} 43.09^{\prime \prime S} \& 7^{\circ} 10^{\prime} 47.35^{\prime \prime S}$ and Longitude $39^{\circ} 6^{\prime} 36.37^{\prime \prime} \mathrm{E} \& 39^{\circ} 33^{\prime} 5.66^{\prime \prime} \mathrm{E}$ at 24 meters above sea level, on the southwestern coast of the Indian Ocean in Tanzania (Figure 1). It covers a total area of 1800 square kilometre, of which 1350 square kilometre is landmass including its eight offshore islands; the rest is water-covered area. The Geographically lowland Dar es Salaam experience typically hot-humid climate greatly influenced by northeast and southeast monsoon. The metropolitan receives an average annual rainfall of $172 \mathrm{~mm}$, average annual temperature of 29-degree Celsius and humidity record of 96 percent in the morning and 67 percent in the afternoon. The coastal shrubs, Miombo woodland, coastal swamps and mangrove trees represent the main natural vegetation cover type in the 100-kilometer coastline of Dar es Salaam. LULC has been changing from natural vegetation to farmlands, human settlements and urban centres leading to increased BE, land degradation, deforestation and biodiversity loss [57] [58] [59]. Governed in five districts of Kigamboni, Temeke, Ilala, Kinondoni and Ubungo; population in the metropolitan grew from 843,090 in 1978 to 5,465,420 in 2016; of which 94 percent are urbanites [48]. Development statistics place Dar es Salaam metropolitan as the most industrialized and urbanized city in Tanzania, as well as a member of the global top ten fastest growing cities [60].

\subsection{SEIs in Dar es Salaam Metropolitan Coastline}

Dar es Salaam metropolitan, home to about 10 percent of the country population 


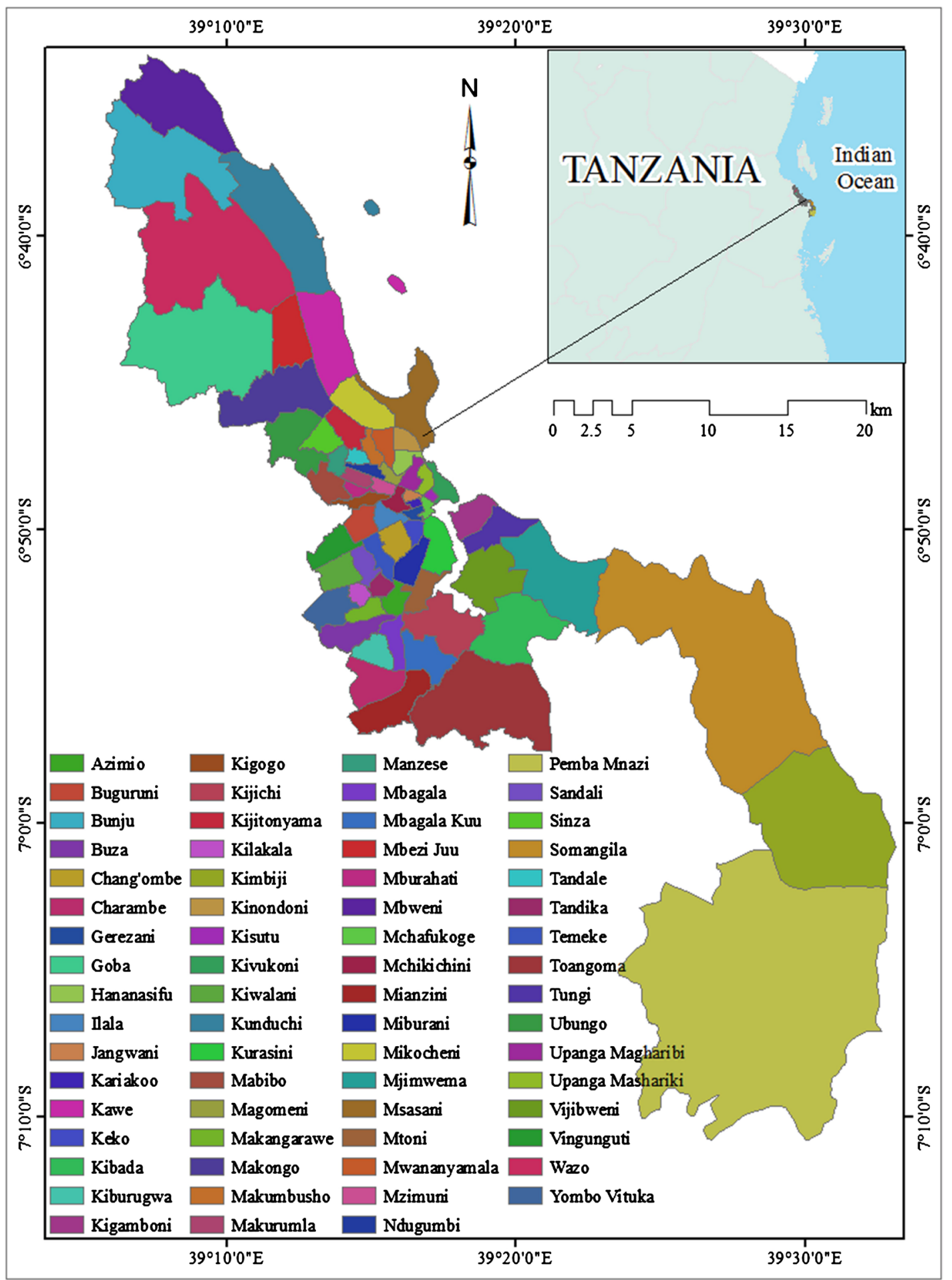

Figure 1. Map of Dar es Salaam metropolitan coastline displaying study area.

estimated to be $55 \mathrm{M}$; at an urbanization rate of 34 percent, is the most industrialized and urbanized city in Tanzania [57]. Growing population, mostly due to rural-urban migration drives city places to experience rapid urbanization and degradation of local environment; consequently, loss of habitat and species, increased noise, air pollution and soil erosion. Studies [61] reveal that rising pop- 
ulation speed-up C \& D activities hence expansion of BE. Moreover, BE expansion indirectly implies encroachment of virgin natural areas for provisioning of construction materials, areas for agricultural activities and places for installing socio-economic infrastructures.

According to [49] Dar es Salaam metropolitan BE development pattern is characterized along the two main rivers, Msimbazi and Mzinga; and four main road namely Nyerere heading to Airport and Kisarawe, Ali Hassan Mwinyi to Bagamoyo, Morogoro that heads to Morogoro region, and Kilwa road that stretches to Lindi region. Kilwa and Ali Hassan Mwinyi roads that are along shoreline are likely to have great influence on SEIs to coastal resources as compared to Nyerere and Morogoro roads that are afar shoreline. Nevertheless, SEIs, as it is to all other environmental impacts, know no borders [62]. The SEIs considered in this research sited in a minimum of 3 kilometre to a maximum of 16.8 kilometer horizontal distance from the seashore along the north-south coast of Dar es Salaam metropolitan.

\subsection{Methods}

\subsubsection{Data and Sources}

The study intended on analyzing BE impacts on socio-ecological system using focus group discussions and Landsat satellite imageries extracted data. Landuse landcover (LULC) statistics (Appendix 1) extracted from Landsat satellite imageries for 1995, 2005 and 2016, freely downloadable from Earth Explorer USGS website. The FGDs involved field survey, to observe, identify and understand socio-ecological issues that community members perceive to affecting their daily livelihoods. Using FGDs, perceived SEIs of BE collected from 67 wards of the study area bordered with Indian Ocean water. Fourteen (14) SEIs (Table 1) that emerged dominant, subjected to further analysis.

\subsubsection{Multi-Criteria Decision Analysis and Weight Generation}

Decision-making is a day-to-day activities we all do, [63] hypothesize that either consciously or unconsciously, good decision depends on the information gathered. According to [64] decision making requires knowledge of the problem and its socio-ecological context, the objective for the decision, criteria for decision-making, stakeholders affected, prioritization of alternative actions and assessment of trade-off. The combination of all these factors results into complexity, such that combination made by integrating all aforementioned factors need a powerful tool of analysis. Achieving good judgment from combined criteria as mentioned above, involves the use of tools such Multi-Attribute Utility Theory, Analytic Hierarchy Process, Fuzzy Set Theory, Case-based Reasoning, Data Envelopment Analysis, Simple Multi-Attribute Rating Technique, Goal Programming, ELECTRE, PROMETHEE, Simple Additive Weighting, and Technique for Order of Preference by Similarity to Ideal Solution. These tools are representative of multicriteria decision analysis (MCDA) [65].

This socio-ecological study used analytical hierarchy process (AHP) to under- 
stand the interactions of socio-ecological impacts (SEIs) along Dar es Salaam metropolitan LULC. The advantage of AHP over other MCDA tools is its capacity to integrating tangible and intangible effects of input variables [66] [67] [68]. In AHP, pairwise comparison square matrix involves assigning values to an element, such that the element in consideration will be a reciprocal of the value of the element in comparison. In AHP method, scale of values to be assigned to an element ranges from 1 (equally important) to 9 (extremely important). In this case, similar criteria being equally important are assigned 1; thus, the value of 1 in the diagonal element of comparison matrix. Dividing each criterion assigned value by the column total in pairwise comparison matrix, form an input on respective criterion in normalization matrix. Each column sum in normalized matrix should be equal to 1 .The weight of each criterion is obtained by dividing each row sum in the normalization matrix by the matrix order; the weight obtained is also referred as eigenvectors.

According to [69], the decision rule is based on consistency ratio (CR), that $\mathrm{CR}<0.1$; this is the validity threshold in AHP method. CR is a ratio of consistency index (CI) and random index (RI) (Equation (2)). In order to get CI (Equation (1)), maximum eigenvalue involves the total sum of product between each column total in pairwise comparison and eigenvector (row average weight) in normalization matrix. The value of RI depends on the matrix order/number of problems (Table 2). The final AHP output (Table 3 and Table 4) provided useful inputs in further analysis in this study.

Table 1. Dar es Salaam coastline socio-ecological impacts (SEIs) of BE.

\begin{tabular}{|c|c|}
\hline Negative criteria of SEIs of BE & Positive criteria of SEIs of BE \\
\hline A. Loss of traditional norms and culture & $\begin{array}{l}\text { J. Enhances social services infrastructural } \\
\text { development }\end{array}$ \\
\hline B. Pollution of terrestrial and hydrological system & K. Create various employment opportunities \\
\hline C. Confrontations/land conflicts & L. Provide income for landlords \\
\hline D. Destruction of landscape and aesthetic & M. Enhances housing services \\
\hline $\begin{array}{l}\text { E. Loss of biodiversity and economically important } \\
\text { trees }\end{array}$ & N. Improves landscaping and aesthetics \\
\hline F. Soil degradation, erosion and loss of fertility & O. Creates novel habitats for biological species \\
\hline G. Source of breeding for flies and diseases vectors & \\
\hline
\end{tabular}

Note: in the rest of the article, numbering letter will represent its SEIs respectively.

Table 2. Lambda maximum/Saaty random consistency index (RI) value.

\begin{tabular}{cccccccccc}
\hline Number of problems (n) & 2 & 3 & 4 & 5 & 6 & 7 & 8 & 9 & 10 \\
Random index (RI) & 0 & 0.58 & 0.90 & 1.12 & 1.24 & 1.32 & 1.41 & 1.45 & 1.51 \\
\hline
\end{tabular}


Table 3. Pairwise comparison matrix on relative weight of negative socio-ecological impacts of built environment.

\begin{tabular}{cccccccccc}
\hline & $\mathrm{A}$ & $\mathrm{B}$ & $\mathrm{C}$ & $\mathrm{D}$ & $\mathrm{E}$ & $\mathrm{F}$ & $\mathrm{G}$ & $\mathrm{H}$ & Weight \\
\hline $\mathrm{A}$ & 1 & $1 / 2$ & $1 / 2$ & $1 / 2$ & $1 / 3$ & $1 / 2$ & $1 / 2$ & $1 / 9$ & 0.043 \\
$\mathrm{~B}$ & 2 & 1 & $1 / 3$ & $1 / 2$ & $1 / 3$ & $1 / 2$ & $1 / 2$ & $1 / 2$ & 0.066 \\
$\mathrm{C}$ & 2 & 3 & 1 & $1 / 2$ & $1 / 2$ & $1 / 3$ & $1 / 2$ & $1 / 3$ & 0.081 \\
$\mathrm{D}$ & 2 & 2 & 2 & 1 & $1 / 2$ & $1 / 2$ & $1 / 3$ & $1 / 2$ & 0.094 \\
$\mathrm{E}$ & 3 & 3 & 2 & 2 & 1 & $1 / 2$ & $1 / 2$ & $1 / 3$ & 0.121 \\
$\mathrm{~F}$ & 2 & 2 & 3 & 2 & 2 & 1 & $1 / 2$ & $1 / 3$ & 0.137 \\
$\mathrm{G}$ & 2 & 2 & 2 & 3 & 2 & 2 & 1 & $1 / 4$ & 0.159 \\
$\mathrm{H}$ & 9 & 2 & 3 & 2 & 3 & 3 & 4 & 1 & 0.299 \\
\hline
\end{tabular}

Maximum eigenvalue $\left(\gamma_{\max }\right)=8.782$; Number of criteria/problems $(n)=8$; Consistency index $(\mathrm{CI})=\left(\gamma_{\max }-\right.$ $n) /(n-1)=0.112$; Random index $(\mathrm{RI})=1.41$; Consistency ratio $(\mathrm{CR})=0.079$.

Table 4. Pairwise comparison matrix on relative weight of positive socio-ecological impacts of built environment.

\begin{tabular}{cccccccc}
\hline & $\mathrm{J}$ & $\mathrm{K}$ & $\mathrm{L}$ & $\mathrm{M}$ & $\mathrm{N}$ & $\mathrm{O}$ & Weight \\
\hline $\mathrm{J}$ & 1 & $1 / 3$ & $1 / 3$ & $1 / 2$ & $1 / 3$ & $1 / 2$ & 0.074 \\
$\mathrm{~K}$ & 2 & 1 & $1 / 3$ & $1 / 2$ & $1 / 3$ & $1 / 2$ & 0.096 \\
$\mathrm{~L}$ & 3 & 3 & 1 & $1 / 2$ & $1 / 2$ & $1 / 3$ & 0.149 \\
$\mathrm{M}$ & 2 & 2 & 2 & 1 & $1 / 2$ & $1 / 2$ & 0.162 \\
$\mathrm{~N}$ & 3 & 3 & 2 & 2 & 1 & $1 / 2$ & 0.233 \\
$\mathrm{O}$ & 2 & 2 & 3 & 2 & 2 & 1 & 0.285 \\
\hline
\end{tabular}

Maximum eigenvalue $\left(\gamma_{\max }\right)=6.438$; Number of criteria/problem $s(n)=6$; Consistency index $(\mathrm{CI})=\left(\gamma_{\max }-\right.$ $n) /(n-1)=0.088$; Random index $(\mathrm{RI})=1.24$; Consistency ratio $(\mathrm{CR})=0.071$.

$$
\begin{gathered}
C I=\frac{\left(\gamma_{\max }-n\right)}{(n-1)} \\
C R=\frac{C I}{R I}
\end{gathered}
$$

where $\mathrm{CI}$ is the consistency ratio;

$\gamma_{\max }$ is the maximum eigenvalue;

$n$ is the number of criteria/matrix order;

CR is consistency ratio;

$\mathrm{RI}$ is random index.

\subsubsection{Geographically Weighted Regression Analysis}

The knowledge of spatially distributed variables and observations though significant, had not been part of statistical analysis methods applied to environmental and social sciences data. Spatial dependence science explains the effect of proximity on value similarities when mapping socioeconomic variables [55] [70]. The science behind various models that make-up GWR appreciates how variables 
vary from one geographical location to another [71]. Statistical analysis of such variability required a special technique, henceforth the use of GWR. Advancement in GIS \& RS science integrated with GWR has enabled statistical analysis on spatially distributed data across a certain geographical area [72]. Furthermore, GWR provides an opportunity to understand the difference of regression parameters and model performance across the study area [73] [74]. This study adopted the Gaussian adaptive kernel type to understand the relationship between vegetation cover as dependent variable and independent variables namely $\mathrm{BE}$ and agriculture. The value of finest bandwidth defined by the GWR algorithm method involves technique such as Akaike Information Criteria (AIC) [75]. The AHP SEIs generated weight at ward level for BE, vegetation and agriculture combined with LULC statistics provided necessary inputs for GWR mapping using ArcMap v10.3.

\subsubsection{Spatial Interpolation and Mapping Impacts of BE}

Spatial interpolation is a useful GIS technique of estimating unmeasured data based on measured samples of the same variables [76] [77]. The advent of remote sensing (RS) and geographical information system (GIS) have proved to solving some challenges emanating from time and financial resources with respect to data access and utilization. Furthermore, physical-legal complexities on data capturing, management and consumption contributed significantly to the wide application of spatial interpolations in environmental sciences, geoscience and continuous spatial surface data [78] [79]. According to [80], interpolation science provide efficient techniques to map and understand continuous spatial phenomenon, in particular the spatio-temporal physical changes on the globe landscape. Studies [80] [81] epitomize that knowing GIS procedures, the quality of the work to be performed and geographical boundaries of the study sites; interpolation offers an opportunity to understand and predict the occurrence, distribution and magnitude of an environmental phenomenon with respect to social and economic factors [82]. Studies [76] [78] [79] [83] exemplify spline, kriging, natural neighbor and inverse distance weighting (IDW) as the commonly used geospatial interpolation methods. In this study, IDW, a geospatial analysis tool that treat values of unsampled point as weighted average of values at points within certain cut-off distance [84] is applied to understanding the distribution pattern of SEIs of BE along Dar es Salaam Metropolitan coastline.

\subsubsection{Panel Regression Analysis}

Working with spatio-temporal data is simply means dealing with space and time-based data. While spatial (space) pertains to observations at a locality, temporal (time) component considers observations over a certain period. The panel data characteristics of carrying cross-sectional and time-series dimensions is key in understanding overall, within and between variations amongst variables [85]. Such knowledge is crucial in change-detection studies like socio-ecological impact analysis. Knowing how variables influence each other, within and between 
gauges the overall interactions henceforth-thoughtful characterization of variables and their relative effects. Furthermore, advantage of panel regression on geographically weighted spatio-temporal data lies in its capacity to amplify sample size, thus more degree of freedom, variability and efficiency for estimation with less collinearity among variables [86].

In this study, panel data involved both geographically weighted vegetation cover as a dependent variable (DV), and agriculture and BE as independent variables (IV). This econometric model in STATA v14.1 did take the form presented in Equation (3).

$$
Y_{i t}=\beta_{0}+\beta_{1} X_{i t}+\cdots+\beta_{k} X_{k, i t}+\left(\alpha+\varepsilon_{i t}\right)
$$

where $Y_{i t}$ represents vegetation cover, entity, $i$ at time, $t$;

$\beta_{0}$ is a model constant;

$\beta_{k}$ is the coefficient for independent variables;

$X_{k, i t}$ represents BE and agriculture;

$\alpha$ is the specific time invariant effects;

$\varepsilon_{i t}$ is the error term.

\section{Results}

\subsection{Modelling Spatial Relationships of SEIs}

The LULC changes AHP weighted data on BE, agriculture and vegetation as variables with respect to positive and negative SEIs, separately analyzed using GWR in ArcMap v10.3. The analysis results displayed a poor relationship between variables in the southern part of the study areas, particularly in year 1995. Contrary to year 1995, in 2005 and 2016, the same section of the study area experienced very strong relationship between variables of on both positive and negative SEIs (Figure 2). Generally, positive and negative SEIs occurred simultaneously.

\subsection{Impact of Built Environment}

Treating vegetation cover as a dependent variable, and $\mathrm{BE}$ and agriculture as independent variables into robust fixed panel regression analysis, revealed significant negative effect of $\mathrm{BE}$ on vegetation cover while agricultural activities displayed insignificant effect on vegetation cover. Table 5 provides detailed analysis results. Furthermore, spatial interpolation using IDW on impact distribution and pattern, displayed the northern section of the study area to experiencing strong impact of $\mathrm{BE}$ than the rest (Figure 3).

\subsection{Results Summary}

Spatial relationship modelling (GWR) displayed simultaneously occurrence of both positive and negative SEIs, nonetheless an obvious changes was observed in the southern part of Dar es Salaam Metropolitan. In 1995 the section displayed a very weak relationship in both positive and negative SEIs as compared to 2005 and 2016 that showed a very strong relationship. Results from spatial distribu- 
tion modelling (IDW) exposed the northern section of Dar es Salaam Metropolitan to be experiencing more impact of $\mathrm{BE}$ than other areas. The highest magnitude of positive SEIs relationship was changed from 0.89 in 1995 to 0.99 in 2016, in similar times interval, negative SEIs similarly changed from 0.91 to 0.99 . Additionally, in 1995 IDW indicated 0.000037 as the lowest negative impacts of BE as compared to 0.000052 in 2016 , in the same time periods, IDW showed 0.000048 as the lowest positive impacts of $\mathrm{BE}$ as compared to 0.000069 in 2016.

(a) Positive SEls Relations in 1995

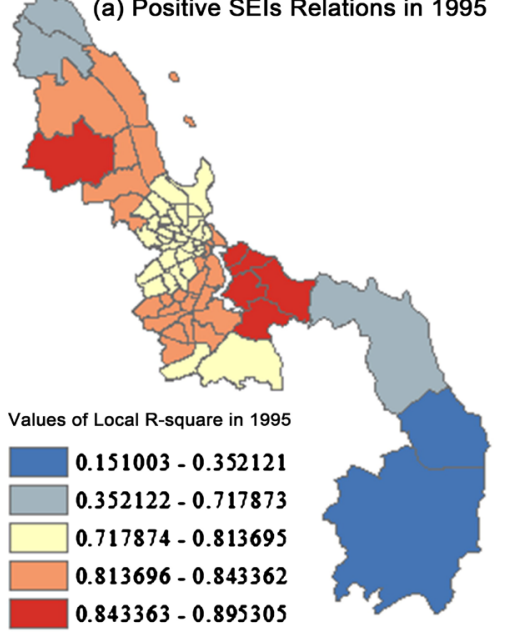

(d) Negative SEls Relations in 1995

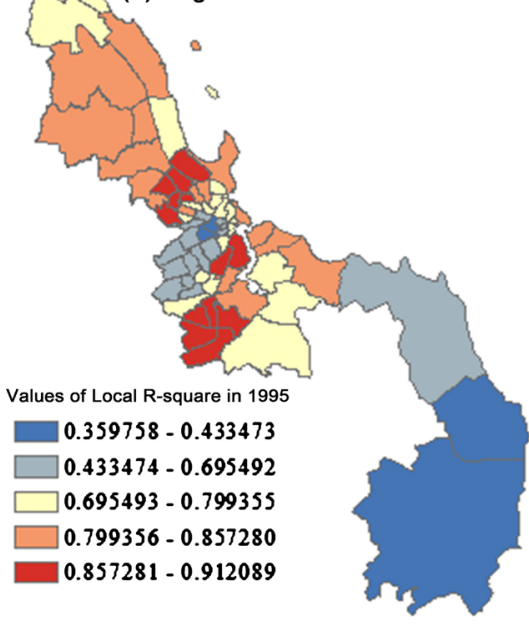

(b) Positive SEls Relations in 2005

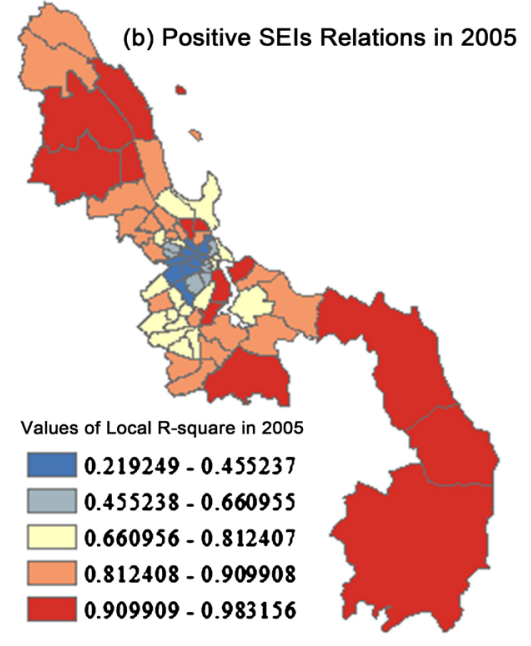

(e) Negative SEls Relations in 2005

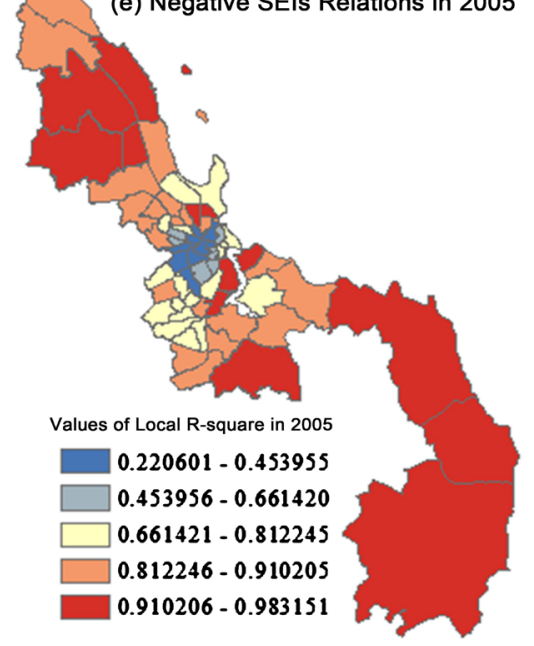

(c) Positive SEls Relations in 2016

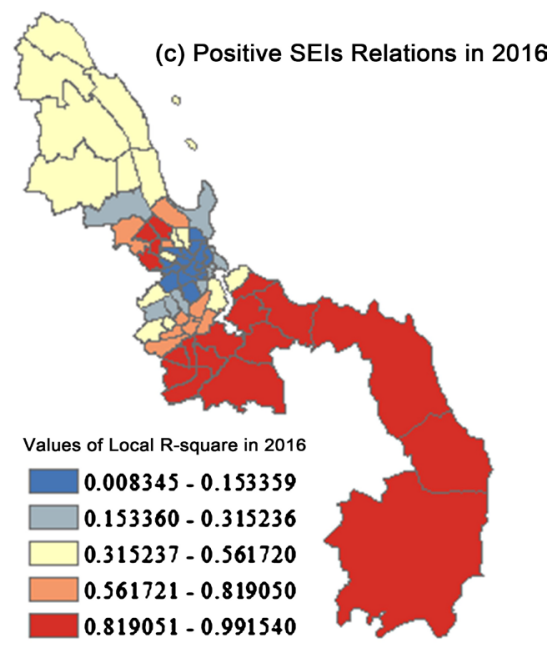

(f) Negative SEls Relations in 2016

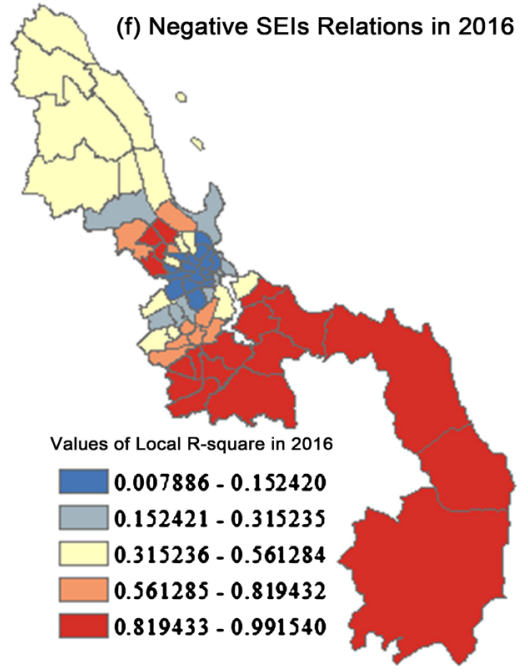

Figure 2. GWR analysis of positive and negative relationships in the study area.

Table 5. Fixed effect panel regression analysis of LULC statistics of the study area.

\begin{tabular}{ccccc}
\hline Vegetation & Coefficient & Standard Error & $\mathrm{t}$ & $\mathrm{P}>|\mathrm{t}|$ \\
\hline Built environment & -0.3405852 & 0.1358987 & -2.51 & 0.015 \\
Agriculture & 0.0599997 & 0.144274 & 0.42 & 0.679 \\
Constant & 0.000272 & $5.07 \mathrm{e}^{-06}$ & 5.37 & 0.000 \\
\hline
\end{tabular}

$\mathrm{R}$ square: within $=0.0358$; between $=0.4356$; overall $=0.3669$. F Statistics $(2,66)=4.76$. Model test $($ Prob $>$ F) $=0.0117$. 
(c) Negative SEI in 2016

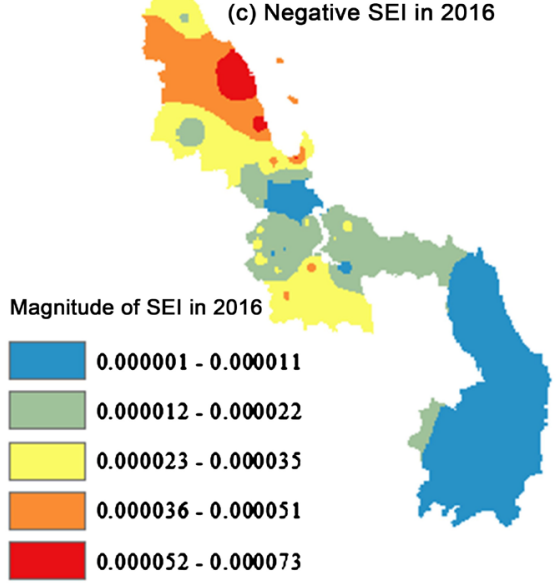

(b) Negative SEI in 2005

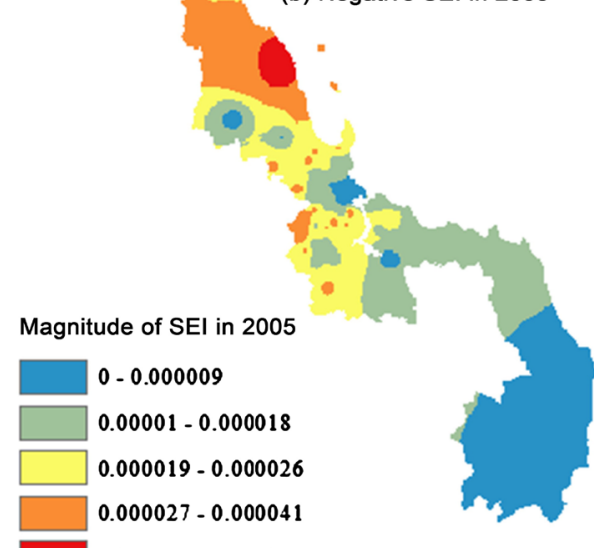

(f) Positive SEI in 2016

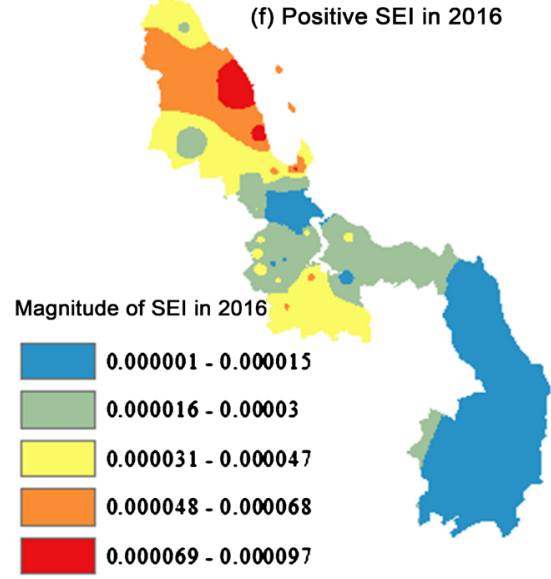

(e) Positive SEI in 2005

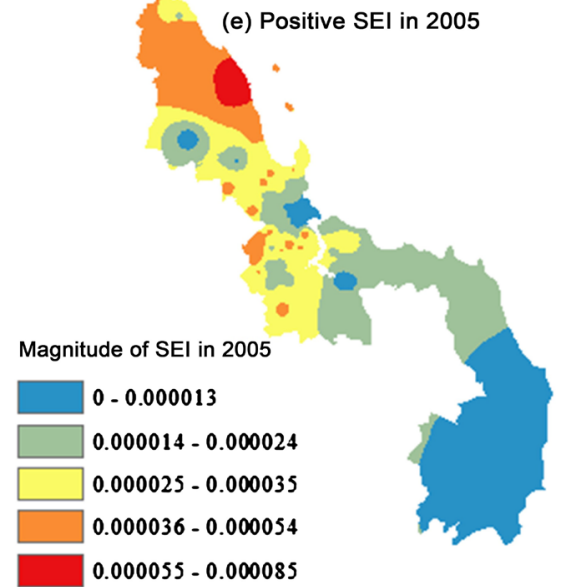

(a) Negative SEI in 1995
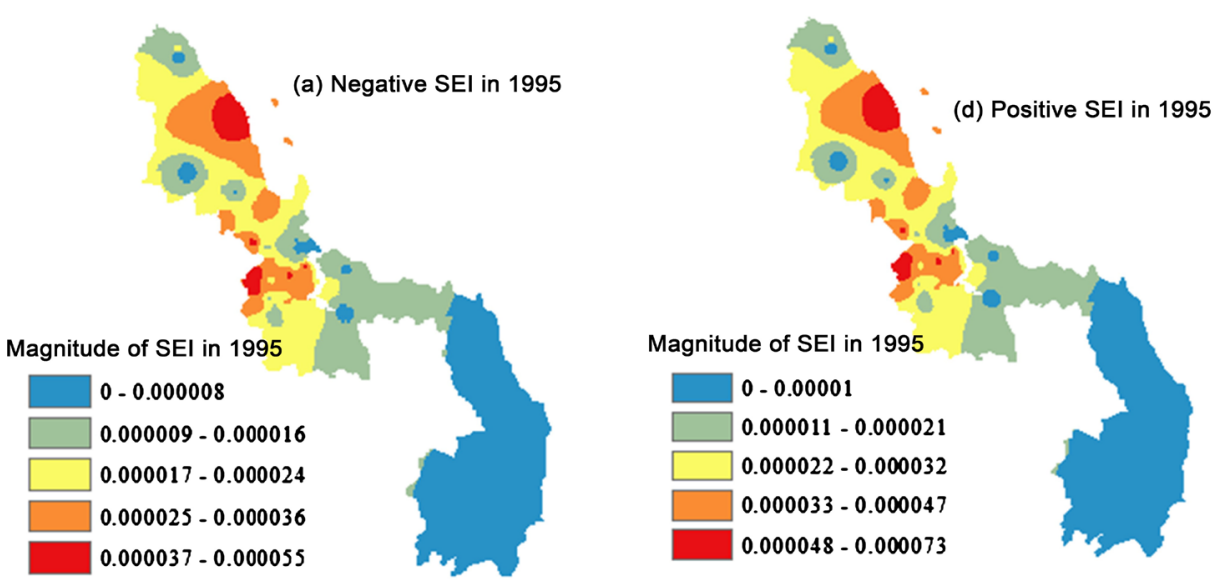

Figure 3. IDW spatial interpolation of BE impacts at Dar es Salaam Coastline.

\section{Discussion}

Study findings revealed that increasing BE decreases vegetation cover; this anthropogenic force influences LULC on the local environment [23]. The LULC changes due to provision of building materials and demand for food is likely to influence negative SEIs like loss of biodiversity and economically important trees, loss/reduction of farm and grazing land, soil degradation, erosion and loss 
of fertility, destruction of landscape and aesthetics and loss of sacred place hence loss of traditional norms and culture. On the other hand, BE, with its construction and demolition waste, wastewater systems, urban runoff channels and stagnant water ponds account for pollution of terrestrial and hydrological system, and breeding sites for flies and diseases vectors.

The positive SEIs of $\mathrm{BE}$ as a product of construction and demolition processes and activities is associated with the desire to enhance social services infrastructure, employment creation, income generation and improvement of aesthetics and landscaping. Novel habitats creation for biological species is positive SEIs of $\mathrm{BE}$, resulting from the interconnectedness of construction and demolition activities but also presence of home trees, flower and backyard gardens. Studies [87] exemplify that urban residential yards and residents' perception on biodiversity and ecosystem services are fundamental to urban novel habitats and biodiversity species presence. In this study, geospatial interpolation (Figure 3) displayed not only increasing but also high magnitude values of positive SEIs across the study period as compared to negative SEIs respectively. The strong spatial relationship of SEIs displayed in the southern part of the study area (Figure 2) is associated with high magnitude of BE impacts in the northern part (Figure 3). Loss of vegetation cover in the southern section of Dar es Salaam Metropolitan could be resulting from increasing BE landscape; resources-rich southern part is the base for construction materials extraction and supply as well as agricultural landscape expansion.

As findings revealed, SEIs observed in the study area is due to land development likely for infrastructure development; which in-turn creates income and employment. Developed land though lead to loss of natural aesthetics; nonetheless, beautify the landscape to suite the appetite of the developer. Consequently, the degraded area once subjected into construction and demolition processes and activities improve to a better scenic as well as for other uses, including species habitats. In practice, the overlapping characteristics of positive and negative SEIs are due to complex intertwined relationship between human being and nature [88], though in all study periods, negative SEIs has low magnitude values than positive SEIs accordingly. Practically strengthened synergies on people-nature connection with respect to nature values and values conservation into construction projects; could be a strategically promising initiative likely to make BE deliver more positive SEI in this fast urbanizing global landscape.

\section{Conclusion}

The study applied analytical hierarchy process (AHP), geographically weighted regression (GWR) analysis, IDW geospatial interpolation and fixed effect panel regression to analyze the SEIs of BE in the coastal line of Dar es Salaam metropolitan. Although positive and negative SEIs occur concurrently, findings and analysis revealed significant changes in southern part of the study area. In the southern part, the magnitude of SEIs changed from very low in 1995 to very high 
in 2016. Panel regression revealed the inverse relationship between BE and vegetation cover; the BE expressed significant negative impact on vegetation cover as compared to agriculture. Therefore, strengthened efforts on people-nature connection, through integrating nature values and conservation initiatives in construction projects could provoke more strategic management of SEIs of BE.

\section{Authors' Contribution}

Mkama Manyama designed the study, collected the data, analyzed and wrote the manuscript. Dr. Cuthbert Nahonyo and Dr. Aloyce Hepelwa supervised the study and revised the manuscript.

\section{Acknowledgements}

Permission by USGS/Earth Explorer to freely access and download all Landsat satellite data for this study.

\section{Conflicts of Interest}

The authors declare no conflicts of interest regarding the publication of this paper.

\section{References}

[1] Galvani, A.P., Bauch, C.T., Anand, M., Singer, B.H. and Levin, S.A. (2016) Human-Environment Interactions in Population and Ecosystem Health. Proceedings of the National Academy of Sciences, 113, 14502-14506. https://doi.org/10.1073/pnas.1618138113

[2] Innes, C., Anand, M. and Bauch, C.T. (2013) The Impact of Human-Environment Interactions on the Stability of Forest-Grassland Mosaic Ecosystems. Scientific Reports, 3, Article No. 2689. https://doi.org/10.1038/srep02689

[3] Haider, L.J., Iribarrem, A., Gardner, T., Latawiec, A.E., Alves-Pinto, H. and Strassburg, B. (2015) Understanding Indicators and Monitoring for Sustainability in the Context of Complex Social-Ecological Systems. In: Sustainability Indicators in Practice, De Gruyter Open, 23-36. https://doi.org/10.1515/9783110450507-007

[4] Mitchell, N.J. and Barrett, B. (2017) Exploring Agricultural Heritage Landscapes: A Journey across “Terra Incognita”. The George Wright Forum, 34, 180-194.

[5] Capello, M., Soria, M., Cotel, P., Deneubourg, J.-L. and Dagorn, L. (2011) Quantifying the Interplay between Environmental and Social Effects on Aggregated-Fish Dynamics. PLoS ONE, 6, e28109. https://doi.org/10.1371/journal.pone.0028109

[6] Cote, M. and Nightingale, A.J. (2012) Resilience Thinking Meets Social Theory: Situating Social Change in Socio-Ecological Systems (SES) Research. Progress in Human Geography, 36, 475-489. https://doi.org/10.1177/0309132511425708

[7] Welsh, M. (2014) Resilience and Responsibility: Governing Uncertainty in a Complex World. The Geographical Journal, 180, 15-26.

https://doi.org/10.1111/geoj.12012

[8] Batista, C.M., Suárez, A. and Saltarén, C.M.B. (2017) Novel Method to Delimitate and Demarcate Coastal Zone Boundaries. Ocean \& Coastal Management, 144, 105-119. https://doi.org/10.1016/j.ocecoaman.2017.04.021 
[9] Mehvar, S., Filatova, T., Dastgheib, A., de Ruyter van Steveninck, E. and Ranasinghe, R. (2018) Quantifying Economic Value of Coastal Ecosystem Services: A Review. Journal of Marine Science and Engineering, 6, 5. https://doi.org/10.3390/jmse6010005

[10] Kummu, M. and Varis, O. (2011) The World by Latitudes: A Global Analysis of Human Population, Development Level and Environment across the North-South Axis over the Past Half Century. Applied Geography, 31, 495-507. https://doi.org/10.1016/j.apgeog.2010.10.009

[11] Kummu, M., De Moel, H., Salvucci, G., Viviroli, D., Ward, P.J. and Varis, O. (2016) Over the Hills and Further Away from Coast: Global Geospatial Patterns of Human and Environment over the 20th-21st Centuries. Environmental Research Letters, 11, 34010. https://doi.org/10.1088/1748-9326/11/3/034010

[12] Aerts, J.C.J.H., Botzen, W.J.W., Emanuel, K., Lin, N., De Moel, H. and Michel-Kerjan, E.O. (2014) Evaluating Flood Resilience Strategies for Coastal Megacities. Science, 344, 473-475. https://doi.org/10.1126/science.1248222

[13] Zari, M.P. (2014) Ecosystem Services Analysis in Response to Biodiversity Loss Caused by the Built Environment. SAPI EN. S. Surveys and Perspectives Integrating Environment and Society.

[14] Gasperi, J., Dris, R., Bonin, T., Rocher, V. and Tassin, B. (2014) Assessment of Floating Plastic Debris in Surface Water along the Seine River. Environmental Pollution, 195, 163-166. https://doi.org/10.1016/j.envpol.2014.09.001

[15] Parris, K.M. (2016) Ecology of Urban Environments. John Wiley \& Sons, Hoboken.

[16] Erb, K.-H. (2012) How a Socio-Ecological Metabolism Approach Can Help to Advance Our Understanding of Changes in Land-Use Intensity. Ecological Economics, 76, 8. https://doi.org/10.1016/j.ecolecon.2012.02.005

[17] Bentley Brymer, A., Holbrook, J., Niemeyer, R., Suazo, A., Wulfhorst, J., Vierling, K., Rachlow, J., et al. (2016) A Social-Ecological Impact Assessment for Public Lands Management: Application of a Conceptual and Methodological Framework. Ecology and Society, 21, 9. https://doi.org/10.5751/ES-08569-210309

[18] Balvanera, P., Quijas, S., Martín-López, B., Barrios, E., Dee, L., Isbell, F., de Groot, R., et al. (2016) The Links between Biodiversity and Ecosystem Services. In: Handbook of Ecosystem Services, Routledge, Abingdon-on-Thames, 45-61. https://doi.org/10.4324/9781315775302-5

[19] Mace, G.M., Norris, K. and Fitter, A.H. (2012) Biodiversity and Ecosystem Services: A Multilayered Relationship. Trends in Ecology \& Evolution, 27, 19-26. https://doi.org/10.1016/j.tree.2011.08.006

[20] You, H. and Yang, X. (2017) Urban Expansion in 30 Megacities of China: Categorizing the Driving Force Profiles to Inform the Urbanization Policy. Land Use Policy, 68, 531-551. https://doi.org/10.1016/j.landusepol.2017.06.020

[21] Subramanian, V. (2012) Coastal Environments: Focus on Asian Coastal Regions. Springer Science \& Business Media, Berlin. https://doi.org/10.1007/978-90-481-3002-3

[22] Villoria Sáez, P., del Río Merino, M. and Porras-Amores, C. (2012) Estimation of Construction and Demolition Waste Volume Generation in New Residential Buildings in Spain. Waste Management \& Research, 30, 137-146. https://doi.org/10.1177/0734242X11423955

[23] Seto, K.C., Güneralp, B. and Hutyra, L.R. (2012) Global Forecasts of Urban Expansion to 2030 and Direct Impacts on Biodiversity and Carbon Pools. Proceedings of the National Academy of Sciences, 109, 16083-16088. 
https://doi.org/10.1073/pnas.1211658109

[24] Tam, V. and Lu, W. (2016) Construction Waste Management Profiles, Practices, and Performance: A Cross-Jurisdictional Analysis in Four Countries. Sustainability, 8, 190. https://doi.org/10.3390/su8020190

[25] Coelho, A. and De Brito, J. (2012) Influence of Construction and Demolition Waste Management on the Environmental Impact of Buildings. Waste Management, 32, 532-541. https://doi.org/10.1016/j.wasman.2011.11.011

[26] Zheng, L., Wu, H., Zhang, H., Duan, H., Wang, J., Jiang, W., Song, Q., et al. (2017) Characterizing the Generation and Flows of Construction and Demolition Waste in China. Construction and Building Materials, 136, 405-413. https://doi.org/10.1016/j.conbuildmat.2017.01.055

[27] Carman, V.G., Machain, N. and Campagna, C. (2015) Legal and Institutional Tools to Mitigate Plastic Pollution Affecting Marine Species: Argentina as a Case Study. Marine Pollution Bulletin, 92, 125-133. https://doi.org/10.1016/j.marpolbul.2014.12.047

[28] Mangi, S.C. (2013) The Impact of Offshore Wind Farms on Marine Ecosystems: A Review Taking an Ecosystem Services Perspective. Proceedings of the IEEE, 101, 999-1009. https://doi.org/10.1109/JPROC.2012.2232251

[29] Lampinen, J., Ruokolainen, K. and Huhta, A.-P. (2015) Urban Power Line Corridors as Novel Habitats for Grassland and Alien Plant Species in South-Western Finland. PLoS ONE, 10, e0142236. https://doi.org/10.1371/journal.pone.0142236

[30] Hobbs, R.J., Higgs, E., Hall, C.M., Bridgewater, P., Chapin III, F.S., Ellis, E.C., Hulvey, K.B., et al. (2014) Managing the Whole Landscape: Historical, Hybrid, and Novel Ecosystems. Frontiers in Ecology and the Environment, 12, 557-564. https://doi.org/10.1890/130300

[31] Medlock, J.M. and Vaux, A.G.C. (2014) Colonization of a Newly Constructed Urban Wetland by Mosquitoes in England: Implications for Nuisance and Vector Species. Journal of Vector Ecology, 39, 249-260. https://doi.org/10.1111/jvec.12099

[32] Lepczyk, C.A., Aronson, M.F.J., Evans, K.L., Goddard, M.A., Lerman, S.B. and MacIvor, J.S. (2017) Biodiversity in the City: Fundamental Questions for Understanding the Ecology of Urban Green Spaces for Biodiversity Conservation. BioScience, 67, 799-807. https://doi.org/10.1093/biosci/bix079

[33] Buczkowski, G. and Richmond, D.S. (2012) The Effect of Urbanization on Ant Abundance and Diversity: A Temporal Examination of Factors Affecting Biodiversity. PLoS ONE, 7, e41729. https://doi.org/10.1371/journal.pone.0041729

[34] Von Glasow, R., Jickells, T.D., Baklanov, A., Carmichael, G.R., Church, T.M., Gallardo, L., Mee, L., et al. (2013) Megacities and Large Urban Agglomerations in the Coastal Zone: Interactions between Atmosphere, Land, and Marine Ecosystems. Ambio, 42, 13-28. https://doi.org/10.1007/s13280-012-0343-9

[35] Fahrig, L., Baudry, J., Brotons, L., Burel, F.G., Crist, T.O., Fuller, R.J., Martin, J., et al. (2011) Functional Landscape Heterogeneity and Animal Biodiversity in Agricultural Landscapes. Ecology Letters, 14, 101-112. https://doi.org/10.1111/j.1461-0248.2010.01559.x

[36] Moffatt, S. and Kohler, N. (2008) Conceptualizing the Built Environment as a Social-Ecological System. Building Research \& Information, 36, 248-268. https://doi.org/10.1080/09613210801928131

[37] Félonneau, M.-L. and Becker, M. (2008) Pro-Environmental Attitudes and Behavior: Revealing Perceived Social Desirability. Revue Internationale de Psychologie 
Sociale, 21, 25-53.

[38] Colding, J. and Barthel, S. (2019) Exploring the Social-Ecological Systems Discourse 20 Years Later. Ecology and Society, 24, Article 2.

https://doi.org/10.5751/ES-10598-240102

[39] Milkoreit, M., Hodbod, J., Baggio, J., Benessaiah, K., Calderón-Contreras, R., Donges, J.F., Werners, S.E., et al. (2018) Defining Tipping Points for Social-Ecological Systems Scholarship-An Interdisciplinary Literature Review. Environmental Research Letters, 13, 33005. https://doi.org/10.1088/1748-9326/aaaa75

[40] Stojanovic, T., McNae, H., Tett, P., Reis, J., Smith, H.D. and Dillingham, I. (2016) The "Social" Aspect of Social-Ecological Systems: A Critique of Analytical Frameworks and Findings from a Multisite Study of Coastal Sustainability. Ecology and Society, 21, 15. https://doi.org/10.5751/ES-08633-210315

[41] Van Gool, F.W.R., Theunissen, N.C.M., Bierbooms, J. and Bongers, I.M.B. (2017) Literature Study from a Social Ecological Perspective on How to Create Flexibility in Healthcare Organisations. International Journal of Healthcare Management, 10, 184-195. https://doi.org/10.1080/20479700.2016.1230581

[42] Solís-Guzmán, J., Rivero-Camacho, C., Alba-Rodríguez, D. and Martínez Rocamora, A. (2018) Carbon Footprint Estimation Tool for Residential Buildings for NonSpecialized Users: OERCO2 Project. Sustainability, 10, 1359. https://doi.org/10.3390/su10051359

[43] Chen, I., Hsieh, C., Kondoh, M., Lin, H., Miki, T., Nakamura, M., Yoshida, T., et al. (2017) Filling the Gaps in Ecological Studies of Socioecological Systems. Ecological Research, 32, 873-885. https://doi.org/10.1007/s11284-017-1521-9

[44] Miller, B.W., Caplow, S.C. and Leslie, P.W. (2012) Feedbacks between Conservation and Social-Ecological Systems. Conservation Biology, 26, 218-227. https://doi.org/10.1111/j.1523-1739.2012.01823.x

[45] Huber, R., Briner, S., Peringer, A., Lauber, S., Seidl, R., Widmer, A., Hirschi, C., et al. (2013) Modeling Social-Ecological Feedback Effects in the Implementation of Payments for Environmental Services in Pasture-Woodlands. Ecology and Society, 18, 41. https://doi.org/10.5751/ES-05487-180241

[46] de Sa, E. and Ardern, C.I. (2014) Associations between the Built Environment, Total, Recreational, and Transit-Related Physical Activity. BMC Public Health, 14, 693. https://doi.org/10.1186/1471-2458-14-693

[47] Champika, L. (2016) Construction in a Changing World. Built Environment Project and Asset Management, 6. https://doi.org/10.1108/BEPAM-02-2016-0002

[48] Worrall, L., Colenbrander, S., Palmer, I., Makene, F., Mushi, D., Mwijage, J., Godfrey, N., et al. (2017) Better Urban Growth in Tanzania: Preliminary Exploration of the Opportunities and Challenges. Coalition for Urban Transitions, London and Washington DC.

[49] Gombe, K.E., Asanuma, I. and Park, J.-G. (2017) Quantification of Annual Urban Growth of Dar es Salaam Tanzania from Landsat Time Series Data. Advances in Remote Sensing, 6, 175. https://doi.org/10.4236/ars.2017.63013

[50] Tarimo, M., Wondimu, P., Odeck, J., Lohne, J. and Lædre, O. (2017) Sustainable Roads in Serengeti National Park: Gravel Roads Construction and Maintenance. Procedia Computer Science, 121, 329-336. https://doi.org/10.1016/j.procs.2017.11.045

[51] Ramage, M.H., Burridge, H., Busse-Wicher, M., Fereday, G., Reynolds, T., Shah, D.U., Densley-Tingley, D., et al. (2017) The Wood from the Trees: The Use of Timber in Construction. Renewable and Sustainable Energy Reviews, 68, 333-359. 
https://doi.org/10.1016/j.rser.2016.09.107

[52] Ofori, G. (2015) Nature of the Construction Industry, Its Needs and Its Development: A Review of Four Decades of Research. Journal of Construction in Developing Countries, 20, 115.

[53] Thomas, N.I.R. and Costa, D.B. (2017) Adoption of Environmental Practices on Construction Sites. Ambiente Construído, 17, 9-24. https://doi.org/10.1590/s1678-86212017000400182

[54] Shirgaokar, M. (2016) Expanding Cities and Vehicle Use in India: Differing Impacts of Built Environment Factors on Scooter and Car Use in Mumbai. Urban Studies, 53, 3296-3316. https://doi.org/10.1177/0042098015608050

[55] Wijayanti, S.P.M., Porphyre, T., Chase-Topping, M., Rainey, S.M., McFarlane, M., Schnettler, E., Kohl, A., et al. (2016) The Importance of Socio-Economic versus Environmental Risk Factors for Reported Dengue Cases in Java, Indonesia. PLoS Neglected Tropical Diseases, 10, e0004964. https://doi.org/10.1371/journal.pntd.0004964

[56] Lenormand, M., Luque, S., Langemeyer, J., Tenerelli, P., Zulian, G., Aalders, I., Van Dijk, J., et al. (2018) Multiscale Socio-Ecological Networks in the Age of Information. PLoS ONE, 13, e0206672. https://doi.org/10.1371/journal.pone.0206672

[57] Mkalawa, C.C. (2016) Analyzing Dar es Salaam Urban Change and Its Spatial Pattern. International Journal of Urban Planning and Transportation, 31, 1138-1150.

[58] Padgham, J., Jabbour, J. and Dietrich, K. (2015) Managing Change and Building Resilience: A Multi-Stressor Analysis of Urban and Peri-Urban Agriculture in Africa and Asia. Urban Climate, 12, 183-204. https://doi.org/10.1016/j.uclim.2015.04.003

[59] Congedo, L. and Munafò, M. (2014) Urban Sprawl as a Factor of Vulnerability to Climate Change: Monitoring Land Cover Change in Dar es Salaam. In: Climate Change Vulnerability in Southern African Cities, Springer, Berlin, 73-88. https://doi.org/10.1007/978-3-319-00672-7_5

[60] Ndetto, E.L. and Matzarakis, A. (2015) Urban Atmospheric Environment and Human Biometeorological Studies in Dar es Salaam, Tanzania. Air Quality, Atmosphere \& Health, 8, 175-191. https://doi.org/10.1007/s11869-014-0261-z

[61] Stow, D.A., Weeks, J.R., Toure, S., Coulter, L.L., Lippitt, C.D. and Ashcroft, E. (2013) Urban Vegetation Cover and Vegetation Change in Accra, Ghana: Connection to Housing Quality. The Professional Geographer, 65, 451-465. https://doi.org/10.1080/00330124.2012.697856

[62] Arouri, M.E.H., Youssef, A.B., M'henni, H. and Rault, C. (2012) Energy Consumption, Economic Growth and $\mathrm{CO}_{2}$ Emissions in Middle East and North African Countries. Energy Policy, 45, 342-349. https://doi.org/10.1016/j.enpol.2012.02.042

[63] Saaty, T.L. (2008) Decision Making with the Analytic Hierarchy Process. International Journal of Services Sciences, 1, 83-98. https://doi.org/10.1504/IJSSCI.2008.017590

[64] Martinez-Harms, M.J., Bryan, B.A., Balvanera, P., Law, E.A., Rhodes, J.R., Possingham, H.P. and Wilson, K.A. (2015) Making Decisions for Managing Ecosystem Services. Biological Conservation, 184, 229-238. https://doi.org/10.1016/j.biocon.2015.01.024

[65] Velasquez, M. and Hester, P.T. (2013) An Analysis of Multi-Criteria Decision Making Methods. International Journal of Operations Research, 10, 56-66.

[66] Jiménez, J.M.M. and Vargas, L.G. (2018) Cognitive Multiple Criteria Decision Making and the Legacy of the Analytic Hierarchy Process. Estudios de Economía Aplicada, 
36, 67-80.

[67] Cinelli, M., Coles, S.R. and Kirwan, K. (2014) Analysis of the Potentials of Multi Criteria Decision Analysis Methods to Conduct Sustainability Assessment. Ecological Indicators, 46, 138-148. https://doi.org/10.1016/j.ecolind.2014.06.011

[68] Saaty, T.L. (2013) The Modern Science of Multicriteria Decision Making and Its Practical Applications: The AHP/ANP Approach. Operations Research, 61, 1101-1118. https://doi.org/10.1287/opre.2013.1197

[69] Saaty, T.L. (1988) What Is the Analytic Hierarchy Process? In: Mitra, G., et al., Eds., Mathematical Models for Decision Support, Springer, Berlin, 109-121. https://doi.org/10.1007/978-3-642-83555-1_5

[70] Harris, P., Fotheringham, A.S., Crespo, R. and Charlton, M. (2010) The Use of Geographically Weighted Regression for Spatial Prediction: An Evaluation of Models Using Simulated Data Sets. Mathematical Geosciences, 42, 657-680. https://doi.org/10.1007/s11004-010-9284-7

[71] Leong, Y.-Y. and Yue, J.C. (2017) A Modification to Geographically Weighted Regression. International Journal of Health Geographics, 16, 11. https://doi.org/10.1186/s12942-017-0085-9

[72] Li, Z., Fotheringham, A.S., Li, W. and Oshan, T. (2019) Fast Geographically Weighted Regression (FastGWR): A Scalable Algorithm to Investigate Spatial Process Heterogeneity in Millions of Observations. International Journal of Geographical Information Science, 33, 155-175. https://doi.org/10.1080/13658816.2018.1521523

[73] Wu, C., Ren, F., Hu, W. and Du, Q. (2019) Multiscale Geographically and Temporally Weighted Regression: Exploring the Spatiotemporal Determinants of Housing Prices. International Journal of Geographical Information Science, 33, 489-511. https://doi.org/10.1080/13658816.2018.1545158

[74] Gollini, I., Lu, B., Charlton, M., Brunsdon, C. and Harris, P. (2013) GWmodel: An R Package for Exploring Spatial Heterogeneity Using Geographically Weighted Models.

[75] Diniz-Filho, J.A.F., Bini, L.M. and Hawkins, B.A. (2003) Spatial Autocorrelation and Red Herrings in Geographical Ecology. Global Ecology and Biogeography, 12, 53-64. https://doi.org/10.1046/j.1466-822X.2003.00322.x

[76] Li, J. and Heap, A.D. (2014) Spatial Interpolation Methods Applied in the Environmental Sciences: A Review. Environmental Modelling \& Software, 53, 173-189. https://doi.org/10.1016/j.envsoft.2013.12.008

[77] Arowolo, A.O. and Deng, X. (2018) Land Use/Land Cover Change and Statistical Modelling of Cultivated Land Change Drivers in Nigeria. Regional Environmental Change, 18, 247-259. https://doi.org/10.1007/s10113-017-1186-5

[78] Singh, C.K., Shashtri, S., Mukherjee, S., Kumari, R., Avatar, R., Singh, A. and Singh, R.P. (2011) Application of GWQI to Assess Effect of Land Use Change on Groundwater Quality in Lower Shiwaliks of Punjab: Remote Sensing and GIS Based Approach. Water Resources Management, 25, 1881-1898.

https://doi.org/10.1007/s11269-011-9779-0

[79] Tang, M., Agrawal, P., Pongpaichet, S. and Jain, R. (2015) Geospatial Interpolation Analytics for Data Streams in Eventshop. IEEE International Conference on Multimedia and Expo, Torino, 29 June-3 July 2015, 1-6. https://doi.org/10.1109/ICME.2015.7177513

[80] Achilleos, G.A. (2011) The Inverse Distance Weighted Interpolation Method and Error Propagation Mechanism-Creating a DEM from an Analogue Topographical Map. Journal of Spatial Science, 56, 283-304. 
https://doi.org/10.1080/14498596.2011.623348

[81] Lam, K.C., Bryant, R.G. and Wainright, J. (2015) Application of Spatial Interpolation Method for Estimating the Spatial Variability of Rainfall in Semiarid New Mexico, USA. Mediterranean Journal of Social Sciences, 6, 108. https://doi.org/10.5901/mjss.2015.v6n4s3p108

[82] Zarco-Perello, S. and Simões, N. (2017) Ordinary Kriging vs Inverse Distance Weighting: Spatial Interpolation of the Sessile Community of Madagascar Reef, Gulf of Mexico. PeerJ, 5, e4078. https://doi.org/10.7717/peerj.4078

[83] Srivastava, P.K., Singh, S.K., Gupta, M., Thakur, J.K. and Mukherjee, S. (2013) Modeling Impact of Land Use Change Trajectories on Groundwater Quality Using Remote Sensing and GIS. Environmental Engineering \& Management Journal, 12, 2343-2355. https://doi.org/10.30638/eemj.2013.287

[84] Mitas, L. and Mitasova, H. (1999) Spatial Interpolation. In: Longley, P.A., et al., Eds., Geographical Information Systems. Principles, Techniques, Management and Applications, 2nd Edition, Wiley, Hoboken.

[85] Huang, J., Zhan, J., Yan, H., Wu, F. and Deng, X. (2013) Evaluation of the Impacts of Land Use on Water Quality: A Case Study in the Chaohu Lake Basin. The Scientific World Journal, 2013, Article ID: 329187. https://doi.org/10.1155/2013/329187

[86] Yu, D. (2010) Exploring Spatiotemporally Varying Regressed Relationships: The Geographically Weighted Panel Regression Analysis. The International Archives of the Photogrammetry, Remote Sensing and Spatial Information Sciences, 38, 134-139.

[87] Belaire, J.A., Westphal, L.M. and Minor, E.S. (2016) Different Social Drivers, Including Perceptions of Urban Wildlife, Explain the Ecological Resources in Residential Landscapes. Landscape Ecology, 31, 401-413. https://doi.org/10.1007/s10980-015-0256-7

[88] Turnhout, E., Waterton, C., Neves, K. and Buizer, M. (2014) Technocratic and Economic Ideals in the Ecosystem Services Discourse. Conservation Letters, 7, 336-337. https://doi.org/10.1111/conl.12069 


\section{Appendix 1. Landuse Lancover (LULC) Change}

\begin{tabular}{|c|c|c|c|c|c|c|c|c|c|c|}
\hline FID & Ward & VEG1995 & AGRIC1995 & BE1995 & VEG2005 & AGRIC2005 & BE2005 & VEG2016 & AGRIC2016 & BE2016 \\
\hline 0 & Azimio & 40 & 16 & 178 & 78 & 6 & 158 & 9 & 21 & 212 \\
\hline 1 & Buguruni & 82 & 25 & 237 & 83 & 13 & 246 & 7 & 82 & 257 \\
\hline 2 & Bunju & 2512 & 714 & 157 & 2091 & 917 & 278 & 280 & 2310 & 748 \\
\hline 3 & Buza & 412 & 61 & 55 & 276 & 145 & 115 & 17 & 160 & 359 \\
\hline 4 & Chang'ombe & 65 & 2 & 276 & 43 & 32 & 269 & 10 & 33 & 300 \\
\hline 5 & Charambe & 532 & 65 & 124 & 242 & 203 & 273 & 23 & 131 & 553 \\
\hline 6 & Gerezani & 14 & 0 & 64 & 10 & 3 & 68 & 3 & 7 & 71 \\
\hline 7 & Goba & 3775 & 780 & 24 & 3522 & 1005 & 48 & 290 & 4055 & 228 \\
\hline 8 & Hananasifu & 58 & 0 & 104 & 77 & 3 & 101 & 20 & 13 & 148 \\
\hline 9 & Ilala & 67 & 1 & 144 & 53 & 8 & 152 & 7 & 27 & 179 \\
\hline 10 & Jangwani & 19 & 0 & 45 & 4 & 1 & 59 & 0 & 6 & 58 \\
\hline 11 & Kariakoo & 0 & 0 & 41 & 0 & 0 & 41 & 0 & 0 & 41 \\
\hline 12 & Kawe & 781 & 460 & 188 & 957 & 198 & 251 & 91 & 471 & 854 \\
\hline 13 & Keko & 34 & 1 & 110 & 23 & 6 & 117 & 3 & 6 & 136 \\
\hline 14 & Kibada & 1492 & 291 & 19 & 1310 & 218 & 31 & 236 & 1175 & 113 \\
\hline 15 & Kiburugwa & 266 & 23 & 102 & 109 & 96 & 187 & 6 & 88 & 293 \\
\hline 16 & Kigamboni & 245 & 52 & 55 & 266 & 73 & 129 & 86 & 160 & 206 \\
\hline 17 & Kigogo & 47 & 1 & 116 & 36 & 2 & 126 & 0 & 17 & 145 \\
\hline 18 & Kijichi & 686 & 277 & 127 & 701 & 243 & 200 & 157 & 431 & 568 \\
\hline 19 & Kijitonyama & 135 & 21 & 236 & 121 & 19 & 252 & 3 & 27 & 363 \\
\hline 20 & Kilakala & 42 & 6 & 104 & 43 & 10 & 100 & 2 & 11 & 139 \\
\hline 21 & Kimbiji & 5239 & 452 & 0 & 3906 & 1684 & 16 & 1454 & 4155 & 36 \\
\hline 22 & Kinondoni & 95 & 2 & 92 & 97 & 4 & 88 & 2 & 7 & 178 \\
\hline 23 & Kisutu & 12 & 0 & 15 & 2 & 0 & 26 & 0 & 1 & 27 \\
\hline 24 & Kivukoni & 139 & 6 & 14 & 101 & 15 & 50 & 16 & 42 & 103 \\
\hline 25 & Kiwalani & 99 & 5 & 324 & 92 & 32 & 306 & 13 & 44 & 371 \\
\hline 26 & Kunduchi & 1718 & 357 & 380 & 1452 & 423 & 555 & 300 & 1068 & 1096 \\
\hline 27 & Kurasini & 151 & 42 & 300 & 129 & 47 & 320 & 21 & 48 & 430 \\
\hline 28 & Mabibo & 84 & 21 & 276 & 79 & 18 & 284 & 5 & 40 & 335 \\
\hline 29 & Magomeni & 40 & 1 & 68 & 36 & 1 & 71 & 8 & 10 & 90 \\
\hline 30 & Makangalawe & 111 & 35 & 93 & 85 & 28 & 124 & 8 & 18 & 210 \\
\hline 31 & Makongo & 1264 & 435 & 48 & 1469 & 194 & 81 & 488 & 895 & 353 \\
\hline 32 & Makumbusho & 22 & 0 & 153 & 17 & 3 & 153 & 1 & 8 & 165 \\
\hline 33 & Makurumla & 11 & 0 & 144 & 17 & 1 & 137 & 1 & 6 & 147 \\
\hline 34 & Manzese & 18 & 4 & 161 & 8 & 2 & 174 & 1 & 5 & 177 \\
\hline
\end{tabular}


M. T. Manyama et al.

\section{Continued}

\begin{tabular}{|c|c|c|c|c|c|c|c|c|c|c|}
\hline 35 & Mbagala & 175 & 45 & 113 & 149 & 43 & 141 & 10 & 60 & 258 \\
\hline 36 & Mbagala Kuu & 407 & 92 & 154 & 351 & 143 & 161 & 42 & 188 & 424 \\
\hline 37 & Mbezi Juu & 599 & 160 & 125 & 609 & 139 & 125 & 23 & 363 & 491 \\
\hline 38 & Mburahati & 25 & 1 & 85 & 20 & 6 & 85 & 2 & 7 & 103 \\
\hline 39 & Mbweni & 1941 & 283 & 10 & 1414 & 546 & 300 & 253 & 1776 & 244 \\
\hline 40 & Mchafukoge & 17 & 0 & 51 & 9 & 1 & 58 & 0 & 7 & 60 \\
\hline 41 & Mchikichini & 80 & 1 & 88 & 72 & 6 & 90 & 31 & 17 & 121 \\
\hline 42 & Mianzini & 546 & 77 & 145 & 460 & 142 & 164 & 45 & 231 & 489 \\
\hline 43 & Miburani & 137 & 25 & 226 & 113 & 41 & 234 & 26 & 69 & 293 \\
\hline 44 & Mikocheni & 373 & 163 & 218 & 475 & 37 & 241 & 37 & 94 & 615 \\
\hline 45 & Mjimwema & 1411 & 784 & 33 & 1741 & 276 & 166 & 297 & 1542 & 362 \\
\hline 46 & Msasani & 544 & 134 & 142 & 686 & 48 & 231 & 51 & 96 & 782 \\
\hline 47 & Mtoni & 103 & 24 & 184 & 125 & 10 & 190 & 50 & 32 & 247 \\
\hline 48 & Mwananyamala & 81 & 3 & 163 & 58 & 4 & 186 & 3 & 16 & 229 \\
\hline 49 & Mzimuni & 33 & 0 & 89 & 27 & 2 & 92 & 4 & 15 & 103 \\
\hline 50 & Ndugumbi & 16 & 0 & 115 & 11 & 2 & 118 & 0 & 2 & 129 \\
\hline 51 & Pemba Mnazi & 18643 & 906 & 0 & 14965 & 4719 & 0 & 6093 & 13667 & 8 \\
\hline 52 & Sandali & 108 & 26 & 139 & 105 & 28 & 141 & 21 & 82 & 170 \\
\hline 53 & Sinza & 165 & 57 & 112 & 99 & 14 & 222 & 6 & 59 & 269 \\
\hline 54 & Somangila & 6950 & 2625 & 39 & 6956 & 2555 & 119 & 2515 & 7190 & 75 \\
\hline 55 & Tandale & 2 & 4 & 109 & 5 & 0 & 110 & 0 & 3 & 113 \\
\hline 56 & Tandika & 26 & 2 & 143 & 20 & 7 & 143 & 5 & 7 & 159 \\
\hline 57 & Temeke & 62 & 6 & 224 & 41 & 19 & 232 & 9 & 29 & 254 \\
\hline 58 & Toangoma & 2582 & 576 & 60 & 2567 & 575 & 136 & 560 & 2363 & 380 \\
\hline 59 & Tungi & 359 & 124 & 105 & 302 & 86 & 225 & 49 & 286 & 257 \\
\hline 60 & Ubungo & 477 & 273 & 192 & 654 & 39 & 247 & 226 & 302 & 413 \\
\hline 61 & Upanga Magharibi & 145 & 0 & 48 & 122 & 7 & 66 & 107 & 9 & 79 \\
\hline 62 & Upanga Mashariki & 67 & 0 & 77 & 54 & 6 & 83 & 16 & 6 & 122 \\
\hline 63 & Vijibweni & 725 & 185 & 127 & 739 & 233 & 147 & 99 & 670 & 330 \\
\hline 64 & Vingunguti & 114 & 17 & 312 & 79 & 17 & 343 & 20 & 60 & 362 \\
\hline 65 & Wazo & 4382 & 705 & 225 & 3492 & 1388 & 292 & 329 & 4104 & 711 \\
\hline 66 & Yombo Vituka & 271 & 39 & 228 & 219 & 85 & 234 & 21 & 115 & 402 \\
\hline
\end{tabular}

